\title{
Comment
}

\section{THE IVANHOE DECISION: THE VALIDITY OF CONTRACTS CONTAINING THE 160 ACRE LIMITATION}

The Central Valley of California has the potential for enormous agricultural development. Nature has blessed the area with fertile soil and a favorable climate, but to realize the potential of the region, a system of water relocation is necessary. A small part of this potential lias been realized through the development of relatively inexpensive storage and distribution facilities, but to take advantage of the bulk of this agrarian wealth required huge irrigation projects for which large amounts of capital were needed.

Early in the history of the state there were numerous proposals for providing the necessary facilities, but lack of funds prevented the construction of the larger projects. A comprehensive irrigation system for the entire valley remained a dream until the federal government entered the project with the necessary money. ${ }^{1}$ Local districts were organized to contract with the federal government for water from these projects, the contracts being entered into subject to judicial review as to their validity. On September 23, 1949, the Ivanhoe Irrigation District entered into such a contract with the United States. ${ }^{2}$ A proceeding was commenced by the district to have the contract validated. The Superior Court held the contract invalid, and its decision was affirmed by a 4-3 decision of the California Supreme Court. ${ }^{3}$ It is felt that to proceed immediately into the detailed rhetoric of the opimion would not result in a clear analysis of the Ivanhoe case and that a better understanding can be achieved by focusing on the key statutes and the issues involved before proceeding to the opinion itself.

\section{OUTLINE OF BACKGROUND IEGISLATION}

The earliest of these statutes is the Wright Act which Cabifornia adopted in $1887,{ }^{4}$ providing a law under which irrigation districts could be established and operated. Included in the general plan was a provision for distribution of water to landowners in proportion to their pro rata share of the last district land assessment. This provision las been codified and is now section 22250 of the Water Code. 5 Also enacted was a provision whereby an irrigation district could raise revenue to pay current operation and maintenance costs by means of direct charges

1 In Ivanhoe Irr. Dist. v. All Parties, 47 Cal. 2d 597, 614, 306 P.2d 824, 834 (I957), the court stated: "As the result of the prolonged studies and planning by the state, the Legislature in 1933 enacted a statute designating the Sacramento-San Joaquin coordinated project as the Central Valley Project, and created the Water Project Authority as an agency of the state to construct, operate and cover the cost of the project, estimated at $\$ 170,000,000 \ldots$. But in those days of depression and unemployment, such bonds were of doubtful or uncertain financial flavor .... [T]hey were not sold and the state turned to the federal government for financial assistance."

2 Ivanhoe Irr. Dist. v. All Parties, 47 Cal.2d 597, 606, 306 P.2d 824, 828 (1957).

3 Ivanhoe Irr. Dist. v. All Parties, 47 Cal. 2d 597, 306 P.2d 824 (1957).

4 Cal. Stat. 1887 , c. 34, p. 29.

5 Cal. Stat. 1943, c. 372 , p. 1897 . Section 22250 reads: "All water distributed by districts for irrigation purposes shall except when otherwise provided in this article be apportioned ratably to each landowner upon the basis of the ratio which the last assessment against his land for district purposes bears to the whole sum assessed in the district for district purposes." 
for the amount of water used. ${ }^{6}$ In Willard v. Glenn-Colusa Irr. Dist., ${ }^{7}$ the California Supreme Court held that where an irrigation district chose to charge for water used and thus did not rely solely on a land assessment for revenue, it did not have to apportion water pursuant to what is now section 22250 . The latter section was treated as the method of distribution to be applied where assessment of land was the only source of revenue. ${ }^{8}$ Other cases have construed section 22250 not to be an absolute requirement but rather one method of distribution to be applied where practicable and where not in conflict with other law. ${ }^{?}$

In 1902, the federal government enacted a Reclamation Act ${ }^{10}$ to accomplish the construction of irrigation systems for the western states. Possibly following the analogy of the Homestead Act, ${ }^{11}$ section 5 of the Reclamation Act required that no one landowner was to receive water for more than 160 acres $^{12}$ of land..$^{13}$ This section was based on a desire to restrict the benefit which any individual could receive from a project built with interest free federal money. ${ }^{14}$ The limitation is applicable not only to projects involving public land but also to those involving lands which were held in private ownership before the project was commenced.10

Also embodied in the 1902 Act was a broad general statement providing for the recognition by the Secretary of the Interior of state law relating to appropriation and distribution of water. ${ }^{16}$ Legislative history dealing with this section

6 Cal. Water COde $\$ 22280$. See also CaL. Water CODE $\$ 22252$.

7201 Cal. 726, 258 Pac. 959 (1927).

8 Willard v. Glenn-Colusa Irr. Dist., 201 Cal. 726, 742, 258 Pac. 959, 966 (1927). The court stated: "Under the strictly assessment plan lands having high valuation and requiring only a small amount of water would, of course, pay a relatively large assessment, in which event the 'owner thereof would be entitled to receive a proportionate amount of water, possibly largely in excess of his needs. On the other hand, land of less value might require a large amount of water .... It might possibly transpire that he would be without sufficient water to meet the requirements of his land .... Such a situation is contrary to every principal of law governing the use of water...."

0 Jenison v. Redfield, 149 Cal. 500, 87 Pac. 62 (1906); Nelson v. Anderson-Cottonwood Irr. Dist., 51 Cal. App. 92, 196 Pac. 292 (1921); Buschmann v. Turlock Irr. Dist., 47 Cal. App. 321, 190 Pac. 491 (1920). See also CaI. Water Code $\$ 22255$.

1032 STAT. 388 (1902), codified in scattered sections of 43 U.S.C. c. 12.

11 Homestead Act of 1862, 12 STAT. 392 (codified in scattered sections of 43 U.S.C. c. 7).

12 Where community property laws are applicable, a married landholder may receive water for 320 acres since 160 acres are attributable to his wife's interest. Note, 38 CALIF. L. REv. 728, 729 (1950).

1332 STAT. 389 (1902), 43 U.S.C. \& 431 (1946).

14 Note, 38 CALIF. L. REv. 728 (1950).

1532 STAT. 388, 389: "No right to the use of water for land in private ownership shall be sold for a tract exceeding one hundred and sixty acres to any one landowner . . ." Section 46 of the Omnibus Adjustment Act of 1926, 44 STAT. 649 (1926), 43 U.S.C. $\$ 423 \mathrm{e}$ (1946) reads in part: "No water shall be delivered upon the completion of any new project or any new division of a project until a contract or contracts shall have been made with an irrigation district ... providing for payment by the district or districts of the cost of construction, operating, and maintaining the works during the time they are in control of the U.S. . . . Such contract or contracts ... shall further provide that all irrigable land beld in private ownership by any one owner in excess of one hundred sixty irrigable acres shall be appraised ... and that no such excess lands so held shall receive water from any project or division if the owners thereof shall refuse to execute valid recordable contracts for the sale of such lands under terms and conditions satisfactory to the Secretary of the Interior and at prices not to exceed those fixed by the Secretary ...." (Emphasis added.) See also Middle Rio Grande W.U. Assn. v. Middle Rio Grande C.D., 57 N.M. 287, 258 P.2d 391 (1953).

16 Section 8 of that act provides: "That nothing in this Act shall be construed as affecting or intended to affect or to in any way interfere with the laws of any state or territory relating to the control, appropriation, use, or distribution of water used in irrigation, or any vested 
is meager, and the exact import is difficult to ascertain from existing case law. In Nebraska v. Wyoming, ${ }^{17}$ the United States Supreme Court held that the Secretary of the Interior, who had appropriated water of the Platte River under Wyoming law, was not an indispensable party to a suit between Wyoming and Nebraska involving their respective rights in this river because if Wyoming had no right to the water, it could confer no right to appropriators. In deciding this point the court discussed section 8 and stated: ${ }^{18}$

All of the acts of the Reclamation Bureau in operating the reservoirs so as to impound and release waters of the river are subject to the authority of Wyoming, and she and her officers are under the duty to administer these waters fairly and impartially .... ... we know as a matter of law that the Secretary of Interior and his agents, acting by the authority of the Reclamation Act and supplementary legislation, must obtain permits and priorities for the use of water from the State of Wyoming and in the same manner as a private appropriator or an irrigation district formed under the state law. His rights can rise no higher than those of Wyoming, and an adjudication of the defendant's [Wyoming's] rights will necessarily bind him.

This rather broad dictum seems to indicate that state law is to control in all instances, but it should be noted that no conflict between the provisions of the Reclamation Act and state law was involved. This case presented one of the situations which section 8 was undoubtedly intended to control. But it seems improbable that Congress intended by this section to render the entire Reclamation Act nugatory whenever state law conflicted with its provisions. ${ }^{19}$

In 1917 , California passed an act ${ }^{20}$ giving irrigation districts authority to contract with the federal government for water from federal projects on terms prescribed by applicable federal laws and rules and regulations made thereunder. ${ }^{21}$

right acquired thereunder and the Secretary of the Interior, in carrying out the provisions of this act shall proceed in conformity with such laws, and nothing herein shall in any way affect any right of any state or of the Federal Government or of any landowner, appropriator, or user of water in, to, or from any interstate stream or of waters thereof; provided, that the right to the use of water acquired under the provisions of this Act shall be appurtenant to the land irrigated and beneficial use shall be the basis, the measure, and the limit of the right." 32 STAT. 390 (1902), 43 U.S.C. $\$ 383$ (1946).

17295 U.S. 40 (1935).

18295 U.S. $40,42,43$ (1935).

19 To the same effect as Nebraska v. Wyoming is United States v. Gerlach Livestock Co., 339 U.S. 725 (1950) which held that $\S 8$ required the federal government to pay for rights vested under state law when they are destroyed by a reclamation project. The case went no further than this. However, in Ivanhoe Irr. Dist. v. All Parties, 47 Cal. 2d 597, 628, 642-43, 306 P.2d 824, 841-42, 851 (1957), the court indicated, relying principally on the Gerlach case, that $\S 8$ would allow state law to control wherever in conflict with federal law. But see Nebraska v. Wyouning, 325 U.S. 589, 615, where the Supreme Court, in dealing with $\$ 8$, expressly pointed out: "We do not suggest that where Congress has provided a system of regulation for federal projects it must give way before an inconsistent state system."

20 Cal. Stat. 1917, c. 160, p. 243.

21 CAI. WATER CODE $\$ 23195$ reads: "Districts may cooperate and contract with the United States under the Federal Reclamation Act of June 17, 1902, and all acts amendatory thereof or supplementary thereto or any other act of Congress heretofore or hereafter enacted permitting cooperation."

CAL. WATER CODE $\$ 23196$ reads in part: "The cooperation and contract may be for any or all of the following purposes: .... (b) A water supply ....."

CAI. WATER CODE $\$ 23197$ reads in part: "In a contract made pursuant to Section 23196 a district may include provision for either or both of the following: (a) Delivery and distribution of water for the land in the district under the relevant acts of Congress and the rules and regulations established thereunder ...."

CAL. WATER CODE $\$ 23200$ reads: "All water, the right to the use of which is acquired by 
This act was codified in $1943^{22}$ and is now section 23175 et seq of the Water Code known as the Irrigation District Federal Cooperation Law.

\section{PROVISIONS INVOLVED IN A TYPICAL CONTRACT}

Following the enactment of these statutes, the Secretary of the Interior, operating under the Omnibus Adjustment Act of $1926^{23}$ and subsequent enactments of Congress, has acquired various water rights in the California Central Valley. ${ }^{24}$ In developing systems for distribution of this water, he has entered into several contracts with local irrigation districts and water agencies. The general pattern of these contracts has been the following: (1) A provision whereby the United States will build or finance the construction of a local distribution system for use of this district. Repayment of this expenditure is provided for under the so-called 9 (d) ${ }^{25}$ provisions whereby the irrigation district repays the principal over a forty year period without interest. At the end of this forty year period, this system becomes the property of the district. (2) Where the project requires the construction of large dams and canals which are to provide water to several districts, it is not feasible to charge any district for these central facilities and give it full title thereto. Therefore, the repayment is accomplished by use of the so-called $9(\mathrm{e})^{26}$ contract whereby the irrigation district pays a fixed amount for the water delivered. This amount is determined by the Secretary of the Interior by apportioning the total cost of the central facility among irrigation, electric power, and flood control and setting a charge for water which will repay the amount allocated to irrigation. These 9 (e) contracts state only the charge which the irrigation district is to pay for water for the next forty years. This charge need not be enougl to return to the United States during the forty year duration of the contract the total cost allocated to irrigation, and the irrigation district is not promised title to the central facilities at the end of that time. (3) Also included are specific provisions concerning the operation of the irrigation district. These include such things as: (a) taxation procedures to protect the United States from default on the payments; (b) a requirement that delivery of water be inade to no more than 160 acres belonging to any one landowner unless he executes a recordable contract to convey within 10 years lands in excess of 160 acres at a price to be set by appraisers; (c) pro-

a district under any contract with the United States shall be distributed and apportioned by the district in accordance with the applicable acts of Congress, the rules and regulations of the Secretary of the Interior thereunder, and the provisions of the contract, and provisions may be made in the contract for the refusal of water service to any or all land which may become delinquent in the payment of any assessment levied for the purpose of carrying out the contract." (Emphasis added.)

22 Cal. Stat. 1943, c. 372, p. 1897.

2344 SтAT. 636 (1926), 43 U.S.C. $\$ 423$ (1946). See note 15 supra.

24 These rights were acquired in three ways: (a) by assignment from the Director of Finance of applications for appropriation which had been made by the state; (b) by the United States making original applications for the appropriation of water, and (c) by purchase of private water rights held by individuals. See Ivanhoe Irr. Dist. v. All Parties, $47 \mathrm{Cal.2d} \mathrm{597,}$ $618,619,306$ P.2d 824, 836 (1957).

It is difficult to see how the majority in the Ivanhoe case found that the water rights which were purchased from private landowners are held in trust by the federal government. See note 38 infra and related text.

25 This method of repaying the federal governnent is authorized in $\$ 9$ (d) of tho Reclamation Projects Act of 1939, 53 STAT. 1195 (1939), 43 U.S.C. $\$ 485 \mathrm{~h}$ (d) (1946), and has been commonly referred to as a " 9 (d) contract."

26 This method of repaying the federal government was authorized in $\$ 9$ (e) of the Reclamation projects Act of 1939, 53 STAT. 1196 (1939), 43 U.S.C. $\$ 485 \mathrm{~h}$ (e) (1946). 
visions that the irrigation district is not to deliver water outside the district nor to any non-agricultural users and that the United States retains title to any waste or seepage waters which come from project water, and (d) provision that the contract is not to be effective until approved by the voters of the irrigation district as required by California law ${ }^{27}$ and validated by a court proceeding. ${ }^{28}$

POSSIBLE ISSUES INVOLVED IN THE VALIDITY OF SUCH A CONTRACT

In determining the validity of contracts including the above provisions, it is clear that the issues presented do not involve the traditional problems of private water litigation, e.g., riparian and appropriative water rights. Rather, the primcipal issue would seem to be whether any provision of the contract is in conflict with the applicable California and United States law. A determination of what is the "applicable law" should involve the interpretation and interrelation of the several statutes, both state and federal. In finding the applicable federal law, one must determine to what extent section 8 of the Reclaination Act was intended to allow conflicting state law to be paramount over federal legislation. In finding the applicable state law, the problem is to what extent sections 23197 (a) and 23200 of the Water Code allow state law to be subordinated to federal law. It is suggested that the following interpretation of section 8 of the Reclamation Act would be a reasonable one. Where the problem involves the acquisition by the United States of water rights, the intent of Congress was that state law should control and that water rights valid under state law should be paid for. But where the question involves the distribution of water by the federal government, the intent was that federal law should control. This view is supported by the absence of special federal laws pertaining to the acquisition of water in contrast to the specific provisions relating to its distribution. ${ }^{29}$ Further, the interpretations placed upon section 8 in the Wyoming v. Nebrask $a^{30}$ and Gerlach $h^{31}$ cases are in harmony with this view. The provisions of the Irrigation District Federal Cooperation Law ${ }^{32}$ could be interpreted to allow California irrigation districts to contract with the United States for water from federal projects on federal terms even though such terms might be in conflict with other state law. This view is supported by the specific language of these sections, ${ }^{33}$ and unless adopted, these sections will have no force or effect whatever. If the above interpretation is valid, then it follows that the provisions of the contract relating to the distribution of water would only be subject to the test of conformity with federal law. However, the California Supreme Court adopted a different approach in the case of Ivanhoe Irr. Dist. v. All Parties. ${ }^{\mathbf{3 4}}$

\section{THE IVANHOE CASE}

The Ivanhoe case involved a contract containing the provisions of the contract outlined above. In the proceeding, the validity of the contract was contested by a

27 CAL. WATER CoDe $\$ \S 23220$ to 23225 inclusive.

28 See Calif. Farar Bureau Federation, Facts on the Water Rights and Other Issues CONFRONTING IrRTgation AND Agriculture 16-56 (2d ed. 1948) which contains the provisions of a typical contract.

29 See note 15 supra.

80295 U.S. 40 (1935).

81 United States v. Gerlach Livestock Co., 339 U.S. 725 (1950).

32 See note 21 supra.

33 CAL. WATER Code $\$ \S 23197 a$ and 23200.

84 47 Cal.2d 597, 306 P.2d 824 (1957). 
bachelor ${ }^{35}$ with 309 acres of land in the Ivanhoe Irrigation District and by the California State Engineer. Attorneys for a corporation with large land holdings in the Central Valley appeared as amicus curiae. The principal grounds for the majority's opinion are somewhat obscure. Its reasoning seems to involve two main theories both of which are apparently necessary to the holding of invalidity. ${ }^{36}$ In evolving the first of these theories the court reasons: California holds all of the unappropriated waters in trust for potential water users; ${ }^{37}$ when the federal governunent obtained water rights for use in the Central Valley Project, its title was obtained subject to this trust; ${ }^{38}$ the terms of this trust are California water law; this law ${ }^{39}$ requires that all lands within a district must be given a pro rata amount of water without limitation. The second of the two theories is that section 8 of the Reclamation Act allows state law to override federal law whenever they are in conflict. ${ }^{40}$ The result of this is that the inclusion of the 160 acre limitation in the contract inakes it invalid.

Whether the foregoing is the legal basis of the opinion cannot be stated with absolute certainty because the court apparently felt it expedient to feint in other directions. Much discussion was devoted to the denial of vested rights without due process of law. ${ }^{41}$ There was language which indicated that the court considered the acreage limitation to be a denial of equal protection of the law. ${ }^{42}$ The opinion also indicated that the section $9(\mathrm{e})^{43}$ contract was a violation of the "debtor-creditor" relationship existing between the irrigation district and the federal government. ${ }^{44}$ In avoiding the application of the Cooperation $\mathrm{Law},{ }^{45}$ the court held that it apphed only in regard to the "applicable" federal law and that the acreage limitation was not applicable to the Central Valley Project. ${ }^{40}$

\section{ANALYSIS OF THE OPINION}

The so-called trust theory pervades unuch of the majority opinion; therefore, an analysis of the opinion unust consider the source and nature of this doctrine. There seems to be no basis in existing case law or statute for the theory. The court

\footnotetext{
35 See note 12 supra.

36 The court, in discussing many legal theories, makes it extremely difficult to determine precisely upon what legal conclusion it based its decision.

37 Ivanhoe Irr. Dist. v. All Parties, 47 Cal. 2d 597, 620, 625, 627, 647, 306 P.2d 824, 837, $840,841,854$ (1957).

38 Id. at $618,625,626,628,642,647,306$ P.2d at 836, 840, 841, 842, 851, 854 (1957).

39 CAL. WATER CODE $\$ 22250$ is taken to be the controlling state law and is held to be the mandatory mode of distribution of water by irrigation districts.

40 Ivanhoe Irr. Dist. v. All Parties, 47 Cal. 2d 597, 627-28, 639, 642-43, 306 P.2d 824, $841-42,849,851$ (1957). This interpretation of $\$ 8$ raises a possible constitutional question as to the delegation of federal legislative powers.

41 Id. at $620,624-25,628,636,648,306 \mathrm{P} .2 \mathrm{~d}$ at $837,840,842,847,854$ (1957).

$42 I d$. at $636,637-38,306$ P.2d at 847,848 (1957).

43 Section 9 of the Reclamation Projects Act of 1939, 53 STAT. 1196 (1939), 43 U.S.C. $\$ 485 \mathrm{~h}$ (1946). See text at note 64 infra.

44 Ivanhoe Irr. Dist. v. All Parties, 47 Cal. 2d 597, 629-30, 631, 639-40, 641, 648, 306 P.2d $824,843-44,849,850-51,854$ (1947).

45 CaL. Water Code $\$ \$ 23175$ et seq.

46 Ivanhoe Irr. Dist. v. All Parties, 47 Cal.2d 597, 637, 638-39, 306 P.2d 824, 848, 849 (1957). The bases of this holding are: (1) The 160 acre limitation was intended to apply only where the water was owned by the federal government in fee. (2) The 160 acre limitation was not intended to he applied to private lands. See note 58 infra and related text, and note 15 supra.
} 
cited some authority, none of which directly supported it. ${ }^{47}$ It seems doubtful that the court seriously intended to incorporate the law of private trusts into the California water law. ${ }^{48}$ However, if this traditional trust law is not to be applicable, then the use of the word "trust" adds nothing but confusion. ${ }^{49}$

It would seem that the court could have put its decision on a firmer legal basis by omitting the discussion of trusts and the trust theory. The court apparently reasoned that without the trust theory, the federal government would hold absoIute title to the water and could distribute it as it thought proper.$^{50}$ However, the court could lrave avoided its discussion of trust law by merely elaborating on its interpretation of section 8,51 i.e., it could have held simply that that section required the Secretary of the Interior to distribute the water in accordance with state law. Under this reasoning the scope of the federal government's title to the water would be immaterial. ${ }^{52}$ If section 8 is uot subject to the interpretation which the court placed upon it, ${ }^{53}$ then the contract cannot be invalidated on the groimd that it conflicts with state law irrespective of the trust theory. ${ }^{54}$ However, accepting the court's interpretation of section 8 , its construction of section 22250 of the Water Code as the applicable state law is somewhat dubious. As pointed out above, ${ }^{55}$ this section has been held previously not to be the exclusive means by which water is to be distributed. But, even if section 22250 is held to be exclusive in most imstances, the later enactment of the Irrigation District Federal Cooperation Law ${ }^{56}$ which deals specifically with water from federal projects would indicate an intention to allow an exception to the generally applicable rule. ${ }^{57}$ The court

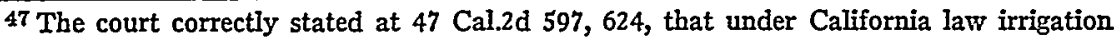
districts are considered to hold title to all district property in trust for the benefit of the land holders of the district citing Merchant's Bank v. Escondido Irr. Dist., 144 Cal. 329, 77 Pac. 937, and Tulare Irrigation Dist. v. Collins, $154 \mathrm{Cal}$. 440, $97 \mathrm{Pac}$. 1124, which cases support that

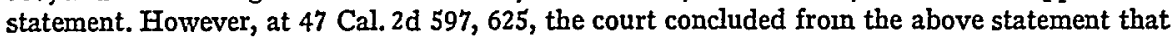
California holds all water in trust for the water users of the state. For authority for this rather dubious proposition (see note 48 infra) the court rehed upon the above cases and Hall v. Superior Court, $198 \mathrm{Cal}$. 373, $245 \mathrm{Pac}$. 814, which also involved the nature of the title of an irrigation district and not that of the state. The Merchant's Bank case supra held that a statute authorizing an irrigation district to give a deed of trust or mortgage was unconstitutional because of trust law principles. One wonders if general trust law is intended to be applied to all waters of the state in the future.

48 See dissenting opinion of Justice Carter, Ivanhoe Irr. Dist. v. All Parties, 47 Cal. d 597, 667-70, 672, 674-76, 306 P.2d 824, 866-68, 869, 871-72 (1957), which points out the anomalous results which would follow.

49 See Ross, Tu-tu, 70 Harv. L. Rev. 812 (1957).

50 Ivanhoe Irr. Dist. v. All Parties, 47 Cal.2d 597, 620, 306 P.2d 824, 837 (1957).

51 See notes 17 and 38 and related text supra.

52 That is, if the federal act requires the Secretary of the Interior to proceed in accordance with state law, he would have to do so even if the federal government held absolute title to the water rights.

53 The writers have suggested above that the apphicability of $\S 8 \mathrm{might}$ not extend so far as to allow all provisions of the Reclamation Act of 1902 and amendinents thereto to be subordinated whenever found to be in conflict with state law. See Nebraska v. Wyoming, 325 U.S. 589,615 , quoted in note 19 supra.

54 U.S. CoNst., art. VI, cl. 2.

65 Willard v. Glenn-Colusa Irr. Dist., 201 Cal. 726, 258 Pac. 959 (1927), and cases cited in note 6 supra.

60 CaL. Water Code $\S 23175$ et seq.

67 In addition to CAL. WATER CODE $\$ \$ 23197$ a and 23200 , $\$ 23179$ makes it evident that this act is intended to give irrigation districts wider powers. It reads: "The board shall perform all acts necessary to carry out the enlarged powers enumerated in this chapter." (Emphasis added.) Cf. Note, 38 CALIF. L. REv. 739, 750 (1950). 
hurdled this obstacle by holding that the acreage limitation was not applicable to California waters because it had never been apphed where the federal government held waters in trust. ${ }^{68}$

The language indicating that the contract was invalid because it denied the landholders due process of law is predicated on the finding of a vested right. But, at the time this contract was entered into, neither the Ivanhoe District nor any of the lands therein had anything in the nature of a vested right to water from this project. They had no riparian rights, had appropriated no water, and had invested neither money nor land in the development of this project. Along with due process, the court mentioned the equal protection clause. ${ }^{59} \mathrm{It}$ is hard to establish a denial of equal protection where the law in question merely places a limitation on the amount which any individual can receive from a federally subsidized ${ }^{00}$ project. $^{01}$ The court's finding of a debtor-creditor relationship between the district and the federal government and use of this to hold that the 9 (e) provisions ${ }^{62}$ of the contract are invalid is apparently without legal support. It cited no authority for the existence of such a relationship. Reference was made to the history of the Central Valley Project, and the conclusion that the federal government was involved only as a creditor seems to be predicated on the fact that "... it appears from the foregoing and the following [history of the Central Valley Project] that the parties contemplated a state project to be eventually owned and operated by the state."0s From this the court reasoned that a debtor (the irrigation district) had to be guaranteed the legal title to the property and the total amount which was to be paid for this title must be specified in the contract. Since the 9 (e) provision of the contract inerely stated how much was to be paid to the federal government during the 40 year duration of the contract and did not provide for transferring legal

68 Ivanhoe Irr. Dist. v. All Parties, 47 Cal. 2d 597, 637, 306 P.2d 824, 848 (1957) : “ . . a diligent search has failed to disclose that the imposition of the limitation has been approved by any court of last resort, either state or federal, in a situation where the federal government had no interest in the lands to be irrigated and possessed only a trustee's interest in the waters to be applied." The lack of such a case could be due to the novelty of the whole trust theory as applied in this case. At 47 Cal. 2 d 597, 638,639, the court stated: ". . . section 46 [Omnibus Adjustment Act of 1926 , note 12 supra] may be deemed to apply to public lands alone." This is in direct conflict with the wording of the section and with the wording of 32 STAT. 389 (1902), 43 U.S.C. $\$ 431$ (1946).

69 See note 40 supra.

60 No interest is charged in the calculation of the amount which must be repaid to the federal government. Where a sun is repaid without interest in 40 equal annual installments, the payments would only pay the interest charge without reducing the principle if the creditor had charged two and one-half per cent interest.

61 The idea that the Constitution requires that the federal government inust distribute a benefit according to the amount of land the recipient owns, or in such manner that everyone receives all that he can use, is not only a novel concept but seems to be in direct conflict with the holding of The Housing Authority v. Dockweiler, 14 Cal. 2d 437, 460, 94 P.2d 794, 806 (1939), where Justice Shenk, speaking for the court, stated: "The state statutes here involved looking to the elimination of slums and the erection in their place and stead of safe and sanitary dwellings of low rent are not fatally defective because of their designation of famihes or persons of low income as the tenants thereof. The legislation does not thereby become class legislation and result in the improper granting of special privileges or immunities to a favored few." If tax-free housing projects may exclude the wealthy and deny them any direct benefits therefrom without violating the equal protection clause, it would seem that an interest-free irrigation project could limit the amount of water which it would deliver to any one person without any equal protection clause objection.

62 Section 9(e) of the Reclamation Project Act of 1939, 53 Stat. 1196 (1939), 43 U.S.C. $\$ 485 \mathrm{~h}(\mathrm{e})(1946)$. See note 28 supra.

63 Ivanhoe Irr. Dist. v. All Parties, 47 Cal. 2d 597, 306 P.2d 824 (1957). 
title to the irrigation district, the court found the clause to be a violation of the "debtor's" rights. ${ }^{64}$ Any legal objection to the 9(e) provisions of the contract is adequately answered in an earher law review comment. ${ }^{65}$

\section{CONCIUSION}

The Ivanhoe case has been appealed to the United States Supreme Court.66 The interpretation placed upon section $8^{67}$ by the California Court will be the primary issue involved in this proceeding. Another issue will be the possible federal review of the state court's interpretation of whether or not the acreage limitation provision of the Reclamation Act is the applicable federal law which the Irrigation District Federal Cooperation Law ${ }^{68}$ incorporated. ${ }^{69}$ While these are the legal issues on which the decision should turn, pohtical and economic considerations will be in the background. ${ }^{70}$ However one inay feel about the desirability of the acreage limitation, it seems probable that the decision of the California Supreme Court will adversely affect future appropriations by Congress for reclamation projects in this state. ${ }^{71}$

John Dutton and Claude Rohwer*

\footnotetext{
64 See note 44 supra and related text.

65 Note, 38 CaLTF. L. Rev. 739 (1950).

66 A motion to dismiss the appeal was denied on October 14, 1957.

67 Section 8, Reclamation Act of 1902, 32 SraT. 390 (1902), 43 U.S.C. $\$ 383$ (1946).

68 Cax. Water Code $\$ 23175$ et seq.

69 For a discussion of the scope of federal review of state law where that law incorporates federal law, see 66. HARV. L. REv. 1498, 1502 (1953).

70 For conflicting viewpoints on this issue, see DowneY, ThEY WouLD RuLE THE VAITEX (ist ed. 1947); Goldschmmt, As You Sow (1st ed. 1947); McWIILIAMs, CaIfrornia, ThIs GrEAT EXCEPTION, c. 17 (1st ed. 1949).

71 See letter attached as Appendix infra; and see Oakland Tribune, Feb. 16, 195\%, p. 4E, col. 1 ; id., Feb. 21, 1957, p.D, col.1; id., April 6, 1957, p.4E, col.3; San Francisco Chronicle, Feb. 16, 1957, p. 4, col.6; id., Feb. 18, 1957, p. 4, col. 5; id., Feb. 25, 1957, p. 14, col.2; id., Mar. 9, 1957, p.4, col. 1 .
}

* Members, Third-Year Class. 


\section{APPENDIX}

\section{COMMITTEE ON INTERIOR AND INSULAR AFFAIRS}

House of Representatives, U.S.

Office of the Chairman

Washington, D.C.

AIR MAIL SPECIAL

February 4, 1957

Honorable Edmund G. (Pat) Brown

Attorney General

State of California

600 State Building

San Francisco 2, California

Dear Pat:

"Enclosed is a copy of a letter the undersigned today sent to Mr. Fred A. Seaton, Secretary of the Interior, in regard to the recent decision of the California Supreme Court in the Ivanhoo case.

"You will observe that this letter refers to our information that you intend to ask for a rehearing in the State Supreme Court, and if that is denied to appeal to the Supreme Court of the United States. We urge you to press for a rehearing and if denied to appeal to the Supreme Court of the United States with the utmost vigor at your command.

"The calamitous effect of this decision on California water devclopment, indeed the reclamation progran for the whole west, is almost too serious to contemplate. We beheve that it could shut down water dehveries under the Central Valley Project for an indefinite period, and very probably end further Federal water development in California.

"If this decision stands, all the present water contracts are illegal. They must bo rewritten. But under what law? Since the 160-acre limitation and the 9 (e) contracts are such an integral part of the Reclamation Law, Congress in such event will have to rewrite large sections of it. In the meantime, water deliveries could not be continued (since a repayment contract is specifically required) in the absence of permissive interim legislation-which itself takes time and is uncertain of passage.

"More fundamentally, and jeopardizing further Federal reclamation projects in California and the entire west, this decision strikes at one of the basic tenets of reclamation law. The moral basis of the 160-acre limitation is to prevent unjust enrichment resulting from the subsidies to irrigation provided by interest-free Federal money and public power revenues. Congress, in our opinion, will not permit the unearned enrichment of large landowners at tho expense of the Federal treasury which can occur without an acreage limitation.

"The capital investment to put water on land under the Central Valley Project averages $\$ 350$ per acre. If an irrigator owns 1,000 acres, the capital investment to serve his land is approximately $\$ 350,000$. This money is interest-free and the interest cost to the federal government over the pay-out period roughly equals the capital investment. In other words, the interest on $\$ 350,000$ over a 50-year period is roughly $\$ 350,000$. This is a direct subsidy to tho irrigator. Using the percentages on repayment referred to in Chief Justice Gibson's dissenting opinion, the irrigator will pay back approximately $\$ 123,000$. The balance of the capital investment will be paid by public power revenues. This amounts to $\$ 227,000$. Thus, the total subsidy to this 1,000 acre irrigator adds up to approximately $\$ 577,000$.

"That is why the supporters of reclamation in the west have insisted on an acreage limitation even though complaining about its inflexibility and the aggravation it has caused tho farmer. The plain fact is that there has to be a limitation, and if under the law Congress cannot impose such a himitation the Federal reclamation program as we have known it will cease to exist for California or any other area.

"The attached letter to Secretary Seaton seeks to keep water development in California going forward during such time as the Ivanhoe case may be on appeal to the Supreme Court of the United States, which we suppose may take as much as a year or two. We sincerely hope when the case gets to the United States Supreme Court you will be successful in reversing tho decision of the California Supreme Court, if that does not occur on a rehearing."

Sincerely yours,

Clair Engle, Chairman

George P. Miller, 8th District

John E. Moss, 3rd District

Harlan Hagen, 14th District

B. F. Sisk, 12th District

J. J. McFall, 11th District 